\title{
PATHOGENESIS OF ASCARIS SUUM IN REPEATED INFECTION OF LAMBS
}

\author{
P. DUBINSKÝ ${ }^{1}$, E. ŠVICKÝ ${ }^{2}$, G. KOVÁC ${ }^{2}$, L. LENHARDT ${ }^{2}$, I. KRUPICER $^{1}$, Z. VASILKOVÁ ${ }^{1}$, \\ E. DVOROŽNÁKKOVÅ ${ }^{1}$, M. LEVKUT ${ }^{2}$, I. PAPAJOVÁ ${ }^{1}$, D. J. MONCOL ${ }^{3}$
}

${ }^{1}$ Parasitological Institute SAS, Košice, Slovak Republic, ${ }^{2}$ University of Veterinary Medicine, Košice, Slovak Republic, ${ }^{3}$ College of Veterinary Medicine, North Carolina State University, Raleigh, USA

Received March 27, 2000

Accepted July 27, 2000

\begin{abstract}
Dubinský P., E. Śvický, G. Kováč, L. Lenhardt, I. Krupicer, Z. Vasilková, E. Dvorožñáková M. Levkut, I. Papajová, D. J. Moncol: Pathogenesis of Ascaris suum in Repeated Infection of Lambs. Acta Vet. Brno 2000, 69: 201-207.

After a repeated long-term infection of lambs with the dose of 100 and 1000 eggs for 23 days only sporadical larvae were detected in the intestines, but they migrated into the liver and the lungs. Clinical signs and biochemical changes were little expressive. Numerous small disseminated greyish white nodules were forming in the liver during infection, the space around the bile ducts and vessels was infiltrated with lymphocytic cells and developing foci were made up of lymphocytes and polymorphonuclear cells. The changes in the lung parenchyma occurred later than in the liver, appearing as disseminated greyish blue nodules. The peribronchial area and interalveolar septa were infiltrated with lymphocytic cells. After infection has been ceased, the restoration of changes in the liver was very rapid, while in the lungs it was slower. An increased alkaline phosphatase and acid phosphatase activities in the intestinal wall induced by larval penetration were persisting and suggested a long-term malabsorption. Despite the mentioned lesions, the infected lambs were able to compensate for the negative influence of migrating Ascaris suum larvae without any conspicuous changes in the concentrations of plasma proteins, albumins, total immunoglobulins, bilirubin and marker enzyme activities.
\end{abstract}

Lambs, non-specific hosts, Ascaris suum, pathogenesis

Postinfective larvae of some nematode species of the suborder Ascaridata are able to migrate also in the organism of non-specific hosts (McDonald and Chevis 1965; Borella et al. 1966). This ability is also possessed by larvae of Ascaris suum, which cause pathomorphological changes in the liver and lungs of lambs and calves (Aitken and Sanford 1968). Some larvae in sheep are even able to reach their maturity. The migration ability of Ascaris suum larvae in ruminants was also confirmed experimentally, when lambs and calves were infected with a single large dose of infective eggs (Fitzgerald 1962; McCraw 1973, 1975). Such an infection, however, occurs only rarely in practice. Non-specific hosts usually come into contact with infective Ascaris eggs in joint enclosures or on pasture grounds manured with pig slurry (B orland et al. 1980; Gunn 1980; Mitchel and Linklater 1980; Gibson and Lanning 1981), or when pigs and cattle are grazed on the same pasture grounds (Thansborg et al. 1999). The eggs in turf and soil develop, survive, and remain infective for a long time (Jurášek et al. 1993). Grazing animals are therefore repeatedly infected usually with small numbers of eggs.

Changes in the organism of lambs were studied after their repeated long-term infection with two different doses of Ascaris suum eggs.

\section{Materials and Methods}

Experiments were conducted on four-month-old lambs of improved Valaška breed. The animals were divided into three groups. Each of six lambs in group 1 was daily infected with 100 eggs and each of 13 lambs in group 2 
with 1000 eggs for 23 days. Control group consisting of five lambs was not infected. The lambs were housed separately in pens and fed with an optimal feeding dose with free access to water.

The eggs were isolated from distal portions of Ascaris suum uteri. They were sedimented and placed in $0.5 \mathrm{~N}$ $\mathrm{NaOH}$ for $15 \mathrm{~min}$, repeatedly washed with distilled water and incubated in $0.1 \mathrm{~N} \mathrm{H}_{2} \mathrm{SO}_{4}$ at $26^{\circ} \mathrm{C}$ for 30 days.

Prior to the experiment and then at 7-day intervals until day 56, the lambs were weighed, their body temperature and respiration rate taken and blood and fecal samples collected. On days 7, 14,21, 28 and 35, one animal of group 2 infected with $1000 \mathrm{~A}$. suum eggs was sacrificed. On days 42 and 56 experiment, i. e. on days 19 and 33 after the last infection, each time three lambs of group 1 and four lambs of group 2 were sacrificed. On day 28 of experiment one lamb and on days 42 and 56 two lambs from control uninfected group were killed each time.

Levels of total proteins, albumins, immunoglobulins and total bilirubin as well as activities of aspartate aminotransferase (AST), alanine aminotransferase (ALT), gamma glutamyltransferase (GGT) and alkaline phosphatase (ALP) were determined spectrophotometrically using Bio-Lachema tests. Samples from the intestine, liver and lungs of dissected animals were taken for histopathological, histochemical and parasitological examination. The intestinal content and mucosal scrapings from the intestine and samples of liver and lungs were examined by the Baerman method for the presence of $A$. suum larvae. Faeces and the intestinal content were examined by a flotation method (Manual of Veterinary Parasitological Techniques 1986). A histopathological examination was performed on paraffin sections stained with haematoxylin-eosin.

Intestinal samples for histochemical examination were frozen within $10 \mathrm{~min}$ and cut into $7 \mu \mathrm{m}$ thick sections on cryostat. Enzyme activities in the intestinal wall were determined by the azocopulation method, with a 30 min incubation at room temperature for alkaline phosphatase and a $15 \mathrm{~min}$ incubation at $37^{\circ} \mathrm{C}$ for acid phosphatase (Lojda et al. 1979). The enzyme activities were evaluated on an integrating microdensitometer VICKERS-M-86 (Germany). The reaction product density was measured with standard use of objective $\times 20$ and screen with diameter of $2 \mu \mathrm{m}$ at optimum length wave (alkaline phosphatase at $480 \mathrm{~nm}$ and acid phosphatase at $520 \mathrm{~nm}$ ). Each enzyme was measured on four intestinal section from each lamb, on 10 intestinal villi and at 10 points. The measured values were evaluated by a one-way ANOVA. Significance of differences was evaluated by Tukey's test.

\section{Results}

Changes in weight and other parameters of the clinical and immunological status of infected and control lambs were published earlier (Krupicer et al. 1999; Levkut et al. 1999).

Examination of the content and scrapings of the digestive system and of feces

Two infective larvae $A$. suum were found in the ruminal content on day 28 of experiment. In the content and scraping from the small and the large intestine and in feces sporadical larvae and eggs A. suum were observed from day 7 to day 28 of experiment. No higher developmental stages of $A$. suum were found in the intestines.

Table 1

Number of Ascaris suum larvae per gram (LPG) in liver and lungs of lambs infected for 23 days with

1000 Ascaris suum eggs a day

\begin{tabular}{|c|c|c|}
\hline $\begin{array}{c}\text { Days of } \\
\text { experiment }\end{array}$ & $\begin{array}{c}\text { Liver } \\
\text { (LPG) }\end{array}$ & $\begin{array}{c}\text { Lungs } \\
\text { (LPG) }\end{array}$ \\
\hline 7 & $2.4 \pm 0.69$ & $1.43 \pm 0.75$ \\
\hline 14 & $1.2 \pm 0.26$ & $1.21 \pm 0.38$ \\
\hline 21 & $0.78 \pm 0.39$ & $1.02 \pm 0.07$ \\
\hline 28 & 0 & 0 \\
\hline 35 & 0 & 0 \\
\hline 42 & 0 & 0 \\
\hline 56 & 0 & 0 \\
\hline
\end{tabular}

\section{Examination of liver and lungs}

Samples of the liver and the lungs weighing $3 \mathrm{~g}$, from lambs of experimental group 2 infected daily with 1000 larvae, were examined by Baerman method in three repetitions. The results (Tab. 1) suggest that the maximum LPG (larvae per gram) value was recorded on day 7 of experiment. The number of larvae in the liver was decreasing more rapidly than 
in the lungs. Larvae were detected only on day 7,14 and 21 of experiment. Control animals showed no presence of larvae.

Table 2

Statistical significance of increased alkaline phosphatase (ALP) and acid phosphatase (ACP) activities in the small intestine of lambs infected with 100 and 1000 Ascaris suum eggs for 23 days compared with control on days 42 and 56 after the last infection.

\begin{tabular}{|c|c|c|c|c|}
\hline \multirow{2}{*}{ Dose of Ascaris suum eggs } & \multicolumn{2}{|c|}{ ALP } & \multicolumn{2}{c|}{ ACP } \\
\cline { 2 - 5 } & Day 42 & Day 56 & Day 42 & Day 56 \\
\hline 100 & $P>0.05$ & $P>0.05$ & $P<0.01$ & $P>0.05$ \\
\hline 1000 & $P<0.001$ & $P>0.05$ & $P<0.001$ & $P<0.01$ \\
\hline
\end{tabular}

Biochemical examination of serum

Biochemical parameters in the blood plasma of control and infected lambs showed no significant changes. Infection of lambs with 100 and $1000 \mathrm{~A}$. suum eggs per day for 23 days neither influenced total proteins which were within the lower range of the standard, nor the levels of albumins and total immunoglobulins. Total bilirubin was standard in all animals (Fig. 1), but in infected lambs higher than in control. Among enzymes studied (ALT, AST, GGT and ALP), infection influenced only ALP activity. Compared with control, the group infected with 100 eggs exhibited statistically insignificantly lower ALP activity (Fig. 2) from day 14 to day 42 , but a statistically significant decrease in the activity was observed on days 49 and $56(P<0.01$ and $P<0.05$, respectively). Administration of 1000 eggs had no effect on ALP activity in lambs.

\section{Pathological examination of liver and lungs}

The liver parenchyma of lambs infected with 1000 eggs and necropsied on days 7 and 14 after infection showed small, inconspicuous greyish white nodules $0.1-0.2 \mathrm{~mm}$ in size. However, on days 21 and 28 even more pronounced greyish white foci, $2 \times 3 \mathrm{~mm}$ large, were observed. On day 35 only sporadical almost invisible greyish white foci were recorded. In

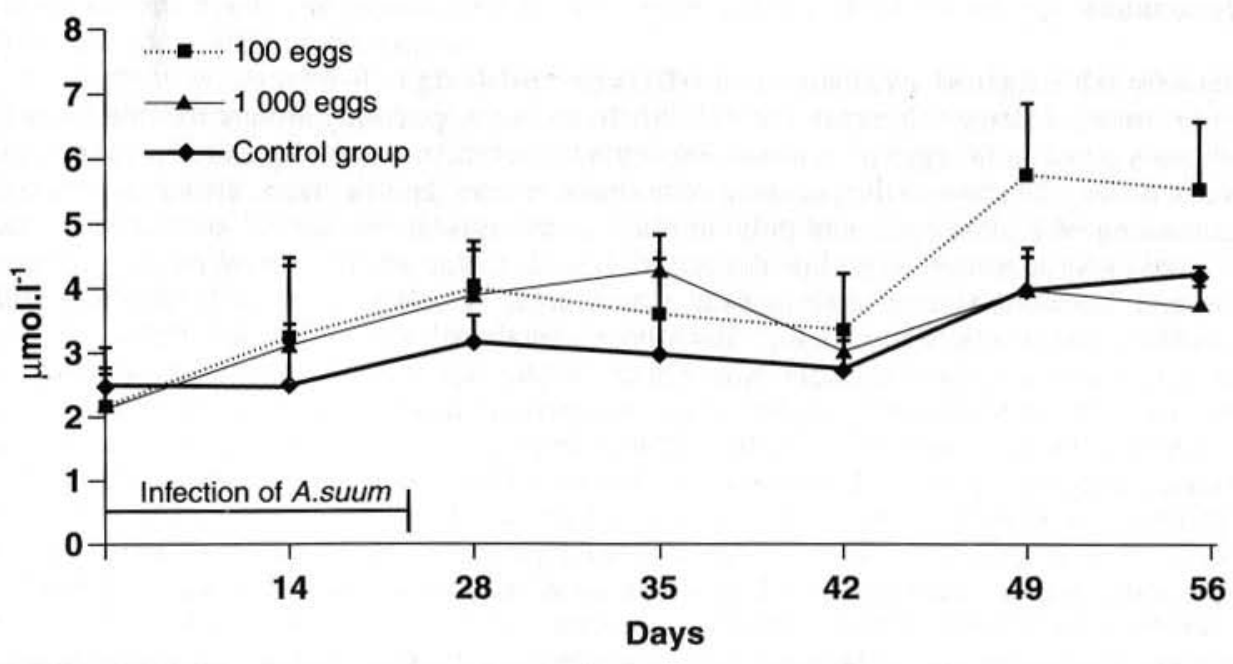




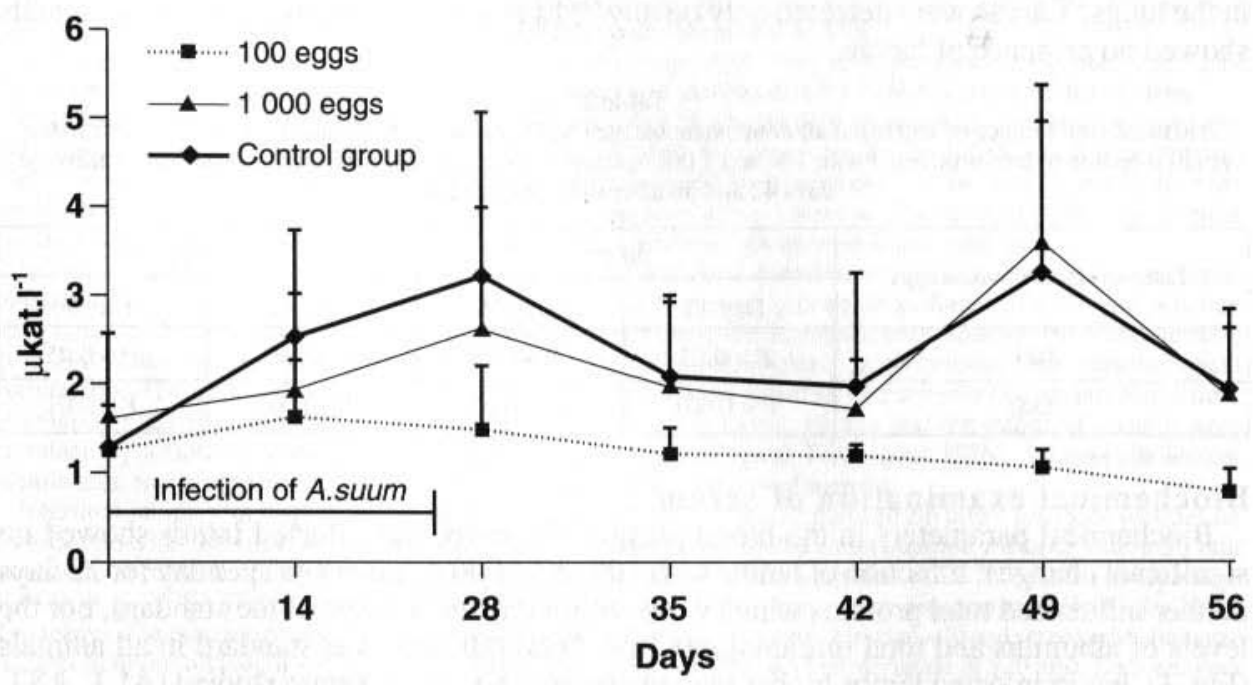

Fig. 2. Alkaline phosphatase in the plasma of lambs infected for 23 days with Ascaris suum eggs

most lambs of both experimental groups examined on days 42 and 56 the liver parenchyma was without visible macroscopical changes, only one animal showed the presence of conspicuous narrow bands, $5-10 \mathrm{~mm}$ long.

The lungs of lambs infected with 1000 eggs were without any macroscopical changes on day 7. On day 14 , sporadical greyish blue nodules, $0.2-0.5 \mathrm{~mm}$ large, were disseminated in the parenchyma. On days 14 and 28 , the nodules were more conspicuous, more abundant and disseminated all over the lung parenchyma. From day 35 the nodules were becoming smaller, fewer and less visible, but persisted in both experimental groups for as late as day 42 when they assumed greyish white colour. On day 56 , the lungs of one lamb from each experimental group showed the presence of greyish white foci, characteristic of verminous pneumonia.

\section{Histopathological examination of liver and lungs}

From day 7, largely lymphocytic cell infiltrates were appearing around the bile ducts in animals given 1000 eggs of $A$. suum. On day 14, the infiltrates also appeared around some vessels. Day 28 showed the presence of nodules around the bile ducts, changing into foci consisting of lymphocytes and polymorphonuclear cells. From day 35 , connective tissue started to form around some bile ducts. On day 42 , inconspicuous eosinophilic infiltrates were still present around some bile ducts and larger vessels in $60 \%$ of lambs from both experimental groups (Plate VI, Fig. 3). Only in a single animal nodules detected in the liver were composed mainly of lymphocytes. On day 49 , the region around some liver vessels and bile ducts was permeated by the forming connective tissue (Plate VI, Fig. 4).

On day 14, the lungs were infiltrated with lymphocytic cells around the bronchi and sporadically also around the interalveolar septa. On day 21 , the peribronchial lymphocytic infiltrates were more conspicuous and sporadical nodules with a cluster of lymphocytes were observed (Plate VII, Fig. 5). On day 35, the peribronchial lymphocytic infiltrate was spreading over a wider area, reaching as for as interalveolar septa. Sporadical clusters of lymphocytes occurred around the bronchi. On day 42 the lung alveoli and bronchi at sites without infiltration and nodules were airy and empty in lambs of both experimental groups. The nodules consisted mostly of lymphocytes, less of polymorphonuclear cells. 
On day 56, the more expressive changes persisted only in the lungs of lambs infected with a higher dose of eggs. The peribronchial area was still infiltrated with lymphocytic cells, penetrating into a wider region as far as interalveolar septa (Plate VII, Fig. 6). The space around some bronchi was infiltrated with a newly forming connective tissue.

\section{Histochemical examination of intestinal wall}

Alkaline phosphatase (ALP) and acid phosphatase (ACP) activities (Table 2) were studied histochemically in the intestinal wall of slaughtered infected and control lambs on days 42 and 56 of experiment.

Relative to control a significantly increased $(P<0.001)$ ALP activity was observed only in lambs given $1000 \mathrm{~A}$. suum eggs (Plate VII, Fig. 7). ACP activity was statistically significantly elevated in both infected groups on day 42 (Plate VII, Fig. 8) and in the group given 1000 eggs for 23 days also on day 56.

The enhanced activity of both the enzymes is likely the result of a repeated migration of A. suum larvae through the intestinal wall and of a subsequent malabsorption.

\section{Discussion}

In studying clinical and pathomorphological changes induced by migrating A. suum larvae in the organism of specific and non-specific hosts, attention is usually paid to the liver and lungs and less to the intestine. However, it is the intestine where the hatched $A$. suum larvae start their migration. Observation of the damage to the intestinal epithelium and subepithelial structures is complicated as to the methods used because of the hardly identifiable site of larva penetration. A long-term administration of infective eggs to lambs, simulating the natural way of animal infection on pasture, entails a repeated damage of intestinal tissues. Such changes are likely to persist for a long time. This has been confirmed by our results, when as late as on day 42 of experiment acid phosphatase activity was increased with even a low repeated dose of eggs (100 specimens). The dose of 1000 eggs also increased the activity of alkaline phosphatase. Acid phosphatase activity, however, remained elevated also on day 56 of experiment. These findings are surprising since changes in the liver faded away relatively early and also restoration of the lungs was observed. The signs of malabsorption after repeated infections may be a serious consequence of pasture parasitoses.

In lambs infected with $40000 \mathrm{~A}$. suum eggs, B rown et al. (1984) reported the damage of the liver on day 6 . This damage was manifested by small necrotic foci infiltrated with eosinophils and lymphocytes. On day 21 only peripheral lymphocytic and eosinophilic clusters persisted. Like in our experiments, also Fitzgerald (1962) reported such infiltrates around bile ducts and vessels with even much more severe $A$. suum infection (80 000 - 40 million eggs ), but he observed neither significant changes nor the presence of larvae in the lamb liver. Similarly Clark et al. (1989) detected no larvae in the liver of lambs naturally infected with $A$. suum, despite conspicuous eosinophilic hepatitis. These findings testify to a different reaction of the liver tissue of pigs and sheep to migrating $A$. suum larvae. Even changes detected in slaughter pigs characterized as "white spots" were indistinct in lambs and remained unnoticed (Brown et al. 1984). Roepstorff et al. (1997) reported numerous "white spots" in the liver of pigs on day 7 post infection with low doses (100,1 000 and 10000$)$ of $A$. suum eggs. Only sporadical lesions persisted from day 21 to day 56 post infection, like in our experiments.

A long-term repeated infection of lambs with 100 and 1000 eggs neither influenced the total bilirubin level nor the activity of aspartate aminotransferase, alanine aminotransferase, alkaline phosphatase and gamma glutamyltransferase. The lamb organism was able to compensate for A. suum infection. A similar conclusion has also been reached by Brown 
et al. (1984), considering that a single infection did not enhance the activity of gammaglutamyltransferase, albumines and total proteins.

The most significant changes caused by migration of $A$. suum larvae were observed in the sheep lungs. They were accompanied by increased temperature from day 6 and increased respiratory rate and cough on days 6 and 7 after the first infection (Krupicer et al. 1999).

After a single infection of lambs with large doses of A. suum eggs, Fitzgerald (1962) reported increased temperature and dyspnoe as early as day 2 , with both the signs persisting until day 8 . Similar symptoms were observed by B rown et al. (1984) on day 5 after single infection but on day 15 , the lambs were without clinical signs.

Unlike in pigs, where it is mostly liver that is severely damaged, migrating A. suum larvae in ruminants induce the most conspicuous changes in the respiratory system. The intensity of signs (dyspnoe, cough etc.) in cattle was determined by the infective dose (Morrow 1968; Greenway and McCraw 1970; McCraw and Lautenslager 1971).

Fitzgerald (1962) reported diffused petechial haemorrhages in the lungs of lambs. On day 21 after a single infection of lambs with 400000 A. suum eggs, Brown et al. (1984) observed a thickening of the interalveolar septa and large clusters of lymphocytes in different parts of the lungs. Similar lesions were also seen in our repeatedly infected animals on days 42 and 56 of experiment. Histopathological changes in the lungs observed on day 42 of experiment are characterized by nodules consisting of lymphocytes. The changes affected not only the area close to the bronchi but extended as far as the interalveolar septa and the pulmonary alveoli.

In grazing cattle naturally infected with A. suum eggs, Morrow (1968) diagnosed diffused interstitial pneumonia. Also McCraw and Lautenslager (1971) reported a thickened alveolar wall and diffused haemorrhages in the alveoli. Both the authors are concordant in stating that interstitial parasitic pneumonia in cattle is very hard to distinguish from other respiratory diseases.

After very high single and repeated doses, A. suum larvae were present in the liver, but more frequently and in higher numbers in the lungs of infected ruminants (Fitzgerald 1962; Morrow 1968; McCraw 1975). Similarily in our experiment on day 7, more larvae were detected in the liver than in the lungs. This number decreased rapidly in the liver, while in the lungs the number of larvae on day 21 was three times higher than in the liver.

Ruminants, sheep in particular, are frequent hosts of adult $A$. suum localized either in the lumen of small intestine (Roneus and Christensson 1979) or in bile ducts (Pedersen et al. 1992). Such non-typical locations of Ascaris suum, however, were also detected in pigs (Suksaithaichana et al. 1989).

\section{Patogenéza Ascaris suum pri opakovanom infikovaní jahniat}

Pri dlhodobom infikovaní jahniat dávkou 100 a 1000 vajičcok denne počas 23 dní sa našli len ojedinelé larvy $\mathrm{v}$ črevách, ale larvy migrovali do pečene a plúc. Klinické prejavy aj biochemické zmeny boli málo výrazné. Počas invadovania sa vytvárali v pečeni početné drobné diseminované sivobiele uzlíky, okolie žlčovodov a ciev bolo infiltrované lymfocytárnymi bunkami a vytvárali sa ložiská tvorené lymfocytmi a polymorfojadernými bunkami. V plúcnom parenchýme sa zmeny objavili neskôr ako $v$ pečeni a prejavili sa diseminovanými sivomodrými uzlíkmi. Okolie bronchov a interalveolárne septá boli infiltrované lymfocytárnymi bunkami. Po ukončení invadovania prebiehala reparácia zmien v pečeni velmi rýchlo, kým v plúcach pomalšie. Zvýšená aktivita alkalickej a kyslej fosfatázy v stene čreva vyvolaná penetráciou lariev pretrvávala a poukazovala na dlhotrvajúcu malabsorpciu. Napriek uvedeným zmenám boli nakazené jahňatá schopné kompenzovat negatívny vplyv migrujúcich lariev Ascaris suum bez výraznejších zmien hladiny plazmových bielkovín, albumínov, celkových imunoglogulínov, bilirubínu, ako aj aktivít markerových enzýmov. 


\section{Aknowiedgements}

This study was supported by the U. S. - Slovak Scientific and Technological Program, Grant No. 002-95 and by the Scientific Grant Agency VEGA, Grant No. 2/5012/98.

\section{References}

AITKEN, M. M., SANFORD, J. 1968: Experimentally induced anaphylaxis in cattle. Vet. Rec. 82: 418-419

BORELLA, L. E., ADAMS, J. G., MALONE, M. H. 1966: The role of histamine in acute experimental ascariasis. J. Parasitol. 52: 295-302

BORLAND, E. D., KEYMER, L. F., COUNTER, D. E. 1980: Condemnation of sheep livers probably due to ascariasis. Vet. Rec. 107: 265-266

BROWN, D., HINTON, M., WRIGHT, A. I. 1984: Parasitic liver damage in lambs with particular reference to the migrating larvae of Ascaris sum. Vet. Rec. 115: 300-303

CLARK, E. G., VON-DEWITZ, A., ACOMPANADO, G. 1989: Spurious Ascaris suum infection in lambs. Can. Vet. J. 30: 903

FITZGERALD, P. R. 1962: The pathogenesis of Ascaris lumbricoides var. summ in lambs. Am. J, vet. Res. 23: 731736

GIBSON, G. McM., LANNING D. G. 1981: Liver damage in lambs. Vet. Rec. 109: 165

GREENWAY, J. A., McCRAW, B. M. 1970: Ascaris sum infection in calves 1. Clinical signs. Can. J. comp. Med. 34: 227-237

GUNN, A. 1980: A case of Ascaris sum infection in lambs. Vet. Rec., 107: 581

JURÁSEK, V., DUBINSKÝ, P. et al. 1993: Veterinárna parazitológia. Bratislava, Príroda. 382 p.

KRUPICER, I., ONDREJKA, R., ŚVICKÝ, E., VASILKOVÁ, Z., DVOROŽNÁKKOVÁ, E., DUBINSKÝ, P., MONCOL, D. J. 1999: Klinické a patomorfologické zmeny v organizme jahniat po dlhodobom infikovaní vajičkami Ascaris suum. Slov, vet. čas. 24: 93-97

LEVKUT, M., REVAJOVÁ, V., DVOROŽNÁKOVÁ, E., REITEROVÁ, K., DUBINSKÝ, P., KRUPICER, I., MONCOL, D. J. 1999: Effect of Ascaris suum reinfection on immunoreactivity in lambs. Helminthologia 36: 69-74

LOJDA, Z., GROSSRAU, R., SCHIEBLER, T. N. 1979: Enzyme Histochemistry. A Laboratory Manual. Springer - Verlag, Berlin, Heidelberg, New York, 339 p

MANUAL OF VETERINARY PARASITOLOGICAL LABORATORY TECHNIQUES 1986, Reference Book, Ministry of Agriculture, Fisheries and Food U.K., $159 \mathrm{p}$

McCRAW, B. M. 1973: Reinfection of yearling calves with Ascaris suum. Can. J. comp. Med. 37: 21-24

McCRAW, B. M. 1975: The development of Ascaris sum in calves. Can. J. comp. Med. 39: 354-357

McCRAW, B. M., LAUTENSLAGER, J. P. 1971: Pneumonia in calves associated with migrating Ascaris suum larvae. Can. Vet. J. 12: 87-90

McDONALD, F. E., CHEVIS, R. A. F. 1965: Ascaris lumbricoides in lambs. N.Z. vet. J. 13: 41-43

MITCHELL, G. B. B., LINKLATER, K. A. 1980: Condemnation of sheep livers due to ascariasis. Vet. Rec. 107: 70-74

MORROW, D. A. 1968: Pneumonia in cattle due to migrating Ascaris lumbricoides larvae. J. Am. vet. med. Ass. 15: $184-189$

PEDERSEN, K., MONRAD, J., HENRIKSEN, S. A., BINSEIL, E., NIELSEN, J. S., JENSEN, E., KNOLD, P. 1992: Ascaris suum infection in lambs. Dansk Veterinaertidsskrift 75: 170-172

ROEPSTORFF, A., ERIKSEN, L., SLOTVED, H. C., NANSEN, P. 1997: Experimental Ascaris suum infection in the pig: Worm population kinetics following single inoculation with three doses in infective eggs. Parasitology 115: $443-452$

RONEUS, O., CHRISTENSSON, D. 1979: Mature Ascaris sum in naturally infected calves. Vet. Parasitol. 3: 371-375

SUKSAITHAICHANA, P., AOUCHAREON, B., EAKPAANITARNPONG, P. 1989: Unusual cases of ascariasis in swine. Thai. J. Vet. Med. 19: 39-46

THANGSBORG, S. M., ROEPSTORFF, A., LARSEN, M. 1999: Integrated and biological control of parasites in organic and conventional production systems. Vet. Parasitol. 84: 169-186 


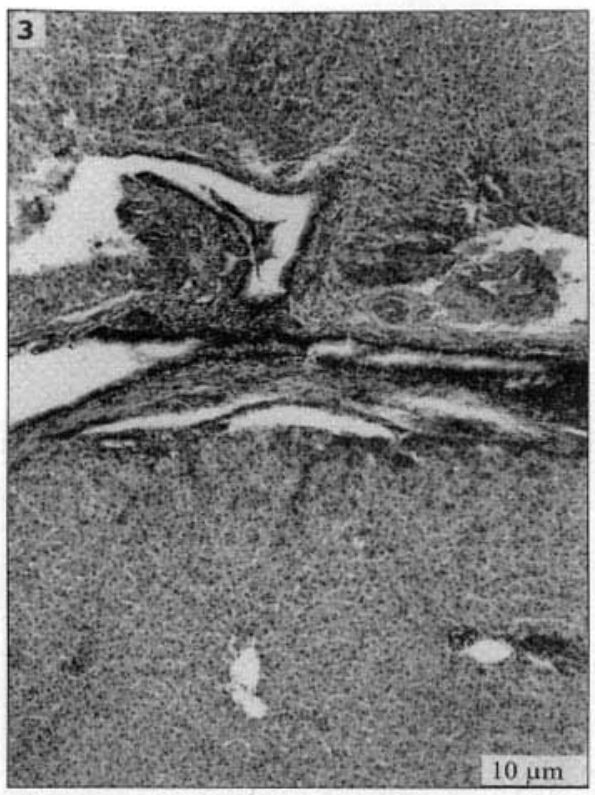

Fig. 3. Lymphocytic infiltrates surrouding the liver bile ducts and large vessels of infected lambs, haematoxylin-eosin

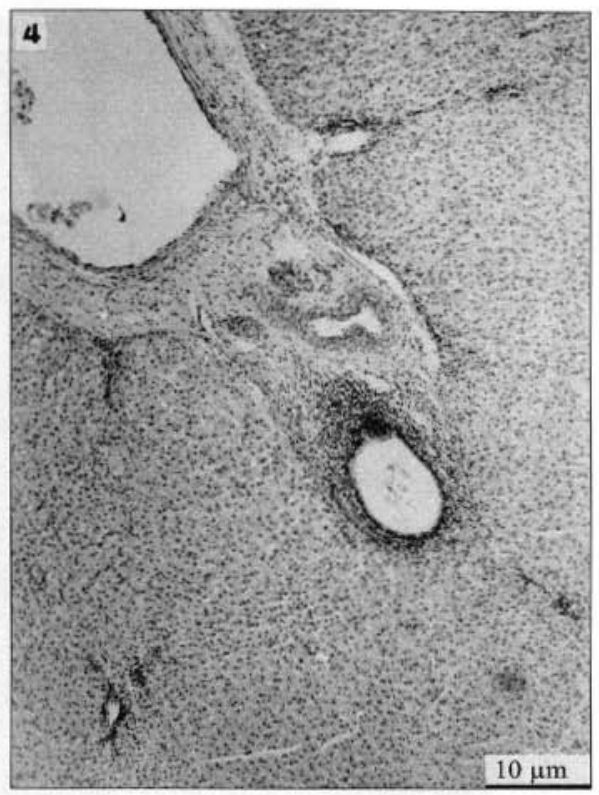

Fig. 4. The space around some liver vessels and bile ducts infiltrated with the forming connective tissue; haematoxylin-eosin

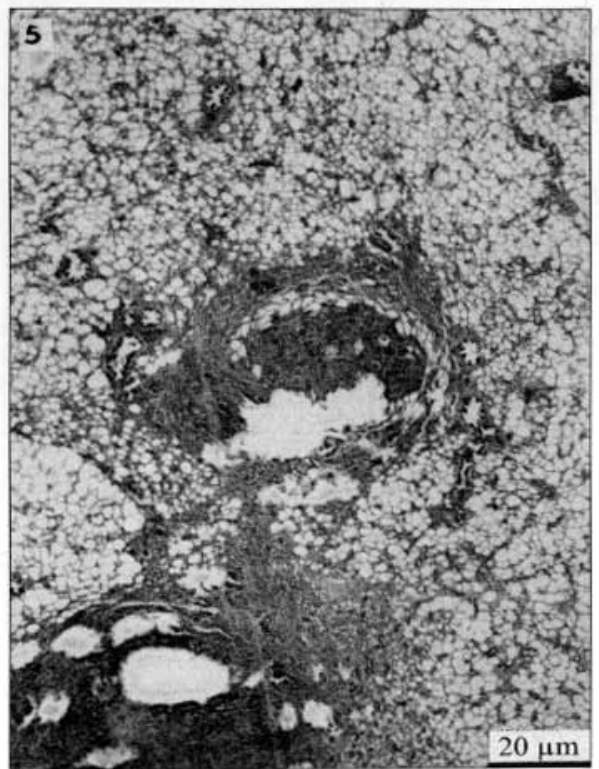

Fig. 5. Nodules consisting of lymphocytes with empty center, in the lung parenchyma; haematoxylin-eosin

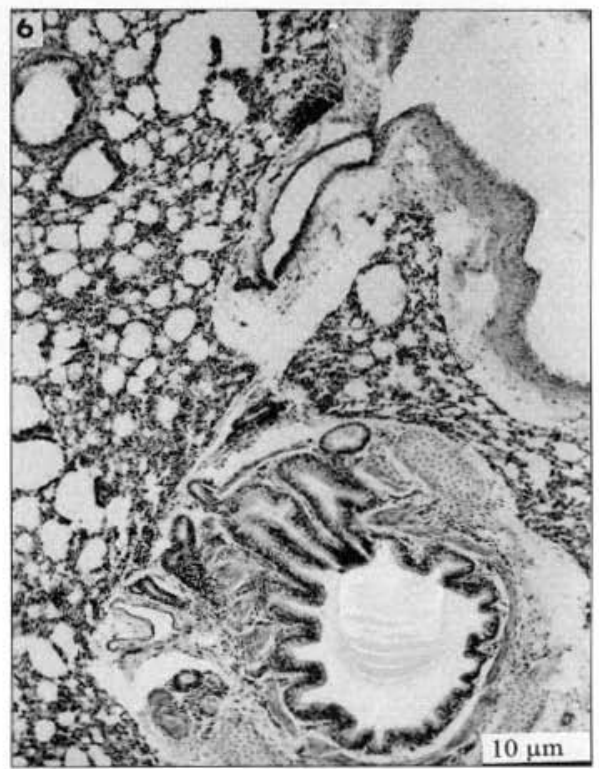

Fig. 6. Space surrounding some bronchi infiltrated with the forming connective tissue, haematoxylineosin 


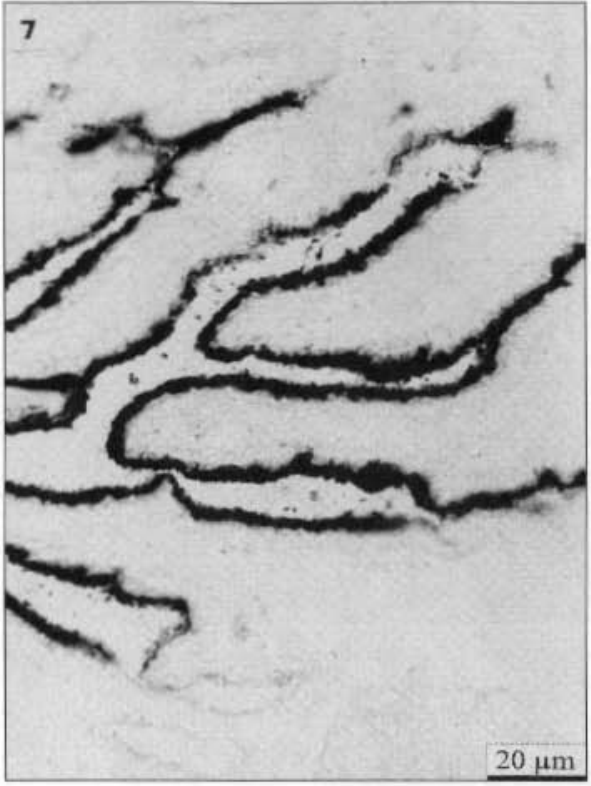

Fig. 7. The high ALP activity in the small intestine of infected lambs on day 42 of experiment; azocopulation method

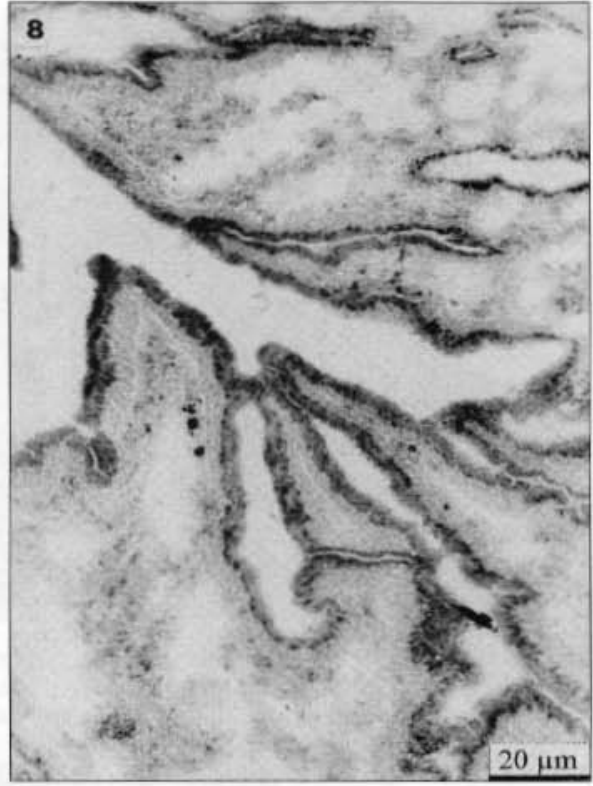

Fig. 8. Enhanced ACP activity in the small intestine of infected lambs on day 42 of experiment; azocopulation method 